\title{
Article \\ Effect of Genotype $\times$ Environment Interaction on Yield of Maize Hybrids in Greece Using AMMI Analysis
}

\author{
Nikolaos Katsenios ${ }^{1} \mathbb{D}$, Panagiotis Sparangis ${ }^{1}\left(\mathbb{D}\right.$, Dimitrios Leonidakis ${ }^{2}$, George Katsaros ${ }^{3}{ }^{(}$, \\ Ioanna Kakabouki ${ }^{4}\left(\mathbb{D}\right.$, Dimitrios Vlachakis ${ }^{5,6,7}$ (D) and Aspasia Efthimiadou ${ }^{1, *(\mathbb{D})}$ \\ 1 Department of Soil Science of Athens, Institute of Soil and Water Resources, Hellenic Agricultural \\ Organization-Demeter, Sofokli Venizelou 1, Lycovrissi, 14123 Attica, Greece; nkatsenios@gmail.com (N.K.); \\ pansparangis@gmail.com (P.S.) \\ 2 Farmacon G.P., K. Therimioti 25, Giannouli, Larisa, 41500 Thessaly, Greece; leo@farmacon.gr \\ 3 Institute of Technology of Agricultural Products, Hellenic Agricultural Organization-Demeter, Sofokli \\ Venizelou 1, Lykovrissi, 14123 Attica, Greece; gkats@chemeng.ntua.gr \\ 4 Laboratory of Agronomy, Department of Crop Science, Agricultural University of Athens, 75 Iera Odos Str., \\ 11855 Athens, Greece; i.kakabouki@gmail.com \\ 5 Laboratory of Genetics, Department of Biotechnology, School of Applied Biology and Biotechnology, \\ Agricultural University of Athens, 11855 Athens, Greece; dimvl@aua.gr \\ 6 Lab of Molecular Endocrinology, Center of Clinical, Experimental Surgery and Translational Research, \\ Biomedical Research Foundation of the Academy of Athens, 11527 Athens, Greece \\ 7 Department of Informatics, Faculty of Natural and Mathematical Sciences, King's College London, Strand, \\ London WC2R 2LS, UK \\ * Correspondence: sissyefthimiadou@gmail.com
}

Citation: Katsenios, N.; Sparangis, P.; Leonidakis, D.; Katsaros, G.;

Kakabouki, I.; Vlachakis, D.;

Efthimiadou, A. Effect of Genotype $\times$ Environment Interaction on Yield of Maize Hybrids in Greece Using AMMI Analysis. Agronomy 2021, 11, 479. https://doi.org/10.3390/ agronomy11030479

Academic Editor: Pedro Revilla

Received: 14 January 2021

Accepted: 3 March 2021

Published: 5 March 2021

Publisher's Note: MDPI stays neutral with regard to jurisdictional claims in published maps and institutional affiliations.

Copyright: (c) 2021 by the authors. Licensee MDPI, Basel, Switzerland. This article is an open access article distributed under the terms and conditions of the Creative Commons Attribution (CC BY) license (https:// creativecommons.org/licenses/by/ $4.0 /)$.
Abstract: An increase in grain yield remains a major target for all involved in maize cultivation. In this study, five maize genotypes were evaluated in a two-year (2017 and 2018) field experiment that was conducted at six locations. Additive main effects and multiplicative interaction (AMMI) analysis was used to detect the narrow adaptations of genotypes in specific mega-environments and the positive interactions of genotypes $(\mathrm{G})$ and environments $(\mathrm{E})$. According to the results of ANOVA, the $G \times E$ interaction effect explained $80.36 \%$ of the variation, while $G$ explained only $12.79 \%$ of the variation, with the remainder explained by E $(6.85 \%)$. The AMMI model indicated that GEN2, GEN4, and GEN5 were the most suitable genotypes for the three mega-environments delineated. Furthermore, GEN4 was found to have a large positive interaction with the environments featuring the highest rain precipitation during the cultivation period, while GEN2 had a large positive interaction with environments where the mean monthly high temperature was over $34^{\circ} \mathrm{C}$, according to the climatic data during the cultivation period. Additionally, the four environments with slightly acidic $\mathrm{pH}$ had a positive interaction with all genotypes of the research, except GEN2.

Keywords: genotype $\times$ environment interaction; maize hybrids; climatic conditions; soil conditions; yield

\section{Introduction}

Maize (Zea mays L.) is a major field crop whose cultivation plays a crucial role in the nutrition of the Earth's increasing population. According to the Food and Agriculture Organization (FAO) [1], from 2012 to 2018, the global production of maize increased by approximately 31\%. Maize, just like many other field crops, usually presents significant differences in terms of performance when it is implemented in different environments. This phenomenon is recognized as the genotype $\times$ environment interaction $(G \times E)$. Therefore, this interaction is required to be assessed before introducing new cultivars that are under development for wide commercial use, as well as when introducing well-known cultivars to new environmental conditions. The main target of this evaluation was to select and separate the genotypes that present a combination of high mean performance and 
reliable stability across multiple environmental trials. According to Duvick [2], the newly developed hybrids are aimed at maintaining a high and stable yield in a wide range of environments. These new hybrids can be successfully identified when tested in different environments. The adaptation of these hybrids is a long-term procedure that requires testing in many locations to be recommended for specific areas [3,4]. As reported by Yan et al. [5], in multiple environmental trials, each genotype presented yield that was affected by the environment $(E)$, the genotype $(G)$, and their interaction $(G \times E)$.

The statistical method used to evaluate the crop yield performance, adaptability, and stability is the additive main effects and multiplicative interaction (AMMI) analysis, which can also distinguish mega-environments [6]. AMMI analysis is now a popular statistical tool that is widely used because it can easily explain the complicated interactions of genotypes and environments [7]. This analysis has been used in a variety of experiments with crops such as wheat [8], maize [9], barley [10], and oilseed rape [11]. In particular, Morgounov et al. [12] used AMMI analysis to evaluate the $G \times E$ interaction for the quality of wheat grain and found that the concentration of $\mathrm{Zn}$ was mainly affected by the location, while Fe concentration was affected by the genotype. In another experiment, Agahi et al. [11] used AMMI analysis to determine the effects of genotype, environment, and their interaction on the grain yield of spring oilseed rape. Similarly, Li et al. [13] tested 20 locations and 10 genotypes in two different years to evaluate wheat yield via the use of AMMI analysis. Da Silveira et al. [14] used AMMI analysis not only to assess the adaptability of sugarcane genotypes, but also to evaluate their phenotypic stability.

AMMI analysis combines ANOVA and PCA (principal component analysis), and the results can be used to assess yield stability in various environments and to determine the most suitable environment for the tested genotypes [11,15]. One crucial output of AMMI analysis is a biplot presenting the mean values of the genotypes and their relationship with the first principal component (PC) [16,17]. A great hybrid as a result of AMMI analysis is one that presents high mean yield along with low variability in multiple environments. In particular, that with the smallest $G \times E$ interaction is the best genotype for wide adaptation [18].

The aim of this study was to evaluate five representative commercial maize hybrids at six locations, where maize has traditionally been cultivated for many decades, for 2 years (the combinations of year and location produced 12 environments), in order to investigate how maize yield was affected by the $G \times E$ interaction and to detect the narrow adaptations of genotypes in specific mega-environments characterized by specific soil and climatic conditions.

\section{Materials and Methods}

\subsection{Experimental Site and Design}

Five maize genotypes (P0937, DKC6050, DKC6442, DKC6980, and PR31Y43) were evaluated in a two-year (2017 and 2018) field experiment conducted at six locations (Giannouli, Giannitsa, NeaTyroloi, Kamila, Kalamonas, and Koutso) where maize has traditionally been cultivated for many decades. The combinations of year and location produced 12 environments for the evaluation of the genotypes (Table 1).

The plant density for all genotypes in every environment was 85,000 plants per hectare, and the planting depth was $3.5 \mathrm{~cm}$. Each experimental plot had a size of $60 \mathrm{~m}^{2}$, consisting of four rows with $0.75 \mathrm{~m}$ spacing between rows. The experiments were conducted in a complete randomized design with two main factors (genotype and environment) and three replications. For the grain yield, $12 \mathrm{~m}$ of the two middle rows was harvested. In order to calculate the production per hectare, right after the harvest, the moisture content of the kernels was measured with a portable humidity meter, and the results of the yield were adjusted to $15 \%$ humidity. 
Table 1. Coordinates, altitude, and cultivation information for the 12 environments of the experiment.

\begin{tabular}{|c|c|c|c|c|c|c|c|}
\hline Environment & Location and Year & Longitude & Latitude & $\begin{array}{c}\text { Meters above Sea } \\
\text { Level }\end{array}$ & Planting Date & Harvesting Date & Plant Density per ha \\
\hline ENV1 & Giannouli 2017 & \multirow{2}{*}{$22^{\circ} 23^{\prime}$} & \multirow{2}{*}{$39^{\circ} 39^{\prime}$} & \multirow{2}{*}{75} & 25 March 2017 & 3 September 2017 & 85,000 \\
\hline ENV2 & Giannouli 2018 & & & & 29 March 2018 & 3 September 2018 & 85,000 \\
\hline ENV3 & Giannitsa 2017 & \multirow{2}{*}{$22^{\circ} 24^{\prime}$} & \multirow{2}{*}{$40^{\circ} 47^{\prime}$} & \multirow{2}{*}{35} & 1 April 2017 & 6 September 2017 & 85,000 \\
\hline ENV4 & Giannitsa 2018 & & & & 20 April 2018 & 7 September 2018 & 85,000 \\
\hline ENV5 & NeaTyroloi 2017 & \multirow{2}{*}{$23^{\circ} 22^{\prime}$} & \multirow{2}{*}{$41^{\circ} 6^{\prime}$} & \multirow{2}{*}{23} & 8 April 2017 & 8 September 2017 & 85,000 \\
\hline ENV6 & NeaTyroloi 2018 & & & & 16 April 2018 & 1 September 2018 & 85,000 \\
\hline ENV7 & Kamila 2017 & \multirow{2}{*}{$23^{\circ} 25^{\prime}$} & \multirow{2}{*}{$41^{\circ} 3^{\prime}$} & \multirow{2}{*}{10} & 1 April 2017 & 7 September 2017 & 85,000 \\
\hline ENV8 & Kamila 2018 & & & & 4 April 2018 & 2 September 2018 & 85,000 \\
\hline ENV9 & Kalamonas 2017 & \multirow{2}{*}{$24^{\circ} 12^{\prime}$} & \multirow{2}{*}{$41^{\circ} 0^{\prime}$} & \multirow{2}{*}{50} & 1 April 2017 & 7 September 2017 & 85,000 \\
\hline ENV10 & Kalamonas 2018 & & & & 14 April 2018 & 1 September 2018 & 85,000 \\
\hline ENV11 & Koutso 2017 & \multirow{2}{*}{$25^{\circ} 1^{\prime}$} & \multirow{2}{*}{$41^{\circ} 2^{\prime}$} & \multirow{2}{*}{10} & 8 April 2017 & 8 September 2017 & 85,000 \\
\hline ENV12 & Koutso 2018 & & & & 4 April 2018 & 31 August 2018 & 85,000 \\
\hline
\end{tabular}

\subsubsection{Climatic Conditions and Soil Physicochemical Properties of the Environments}

The six locations were Giannouli, in the Prefecture of Larissa, Thessaly; Giannitsa, in the Prefecture of Pella, Central Macedonia; NeaTyroloi and Kamila, in the Prefecture of Serres, Central Macedonia; Kalamonas, in the Prefecture of Drama, Eastern Macedonia; and Thrace and Koutso, in the Prefectures of Xanthi, Eastern Macedonia and Thrace, Greece. These locations are considered favorable for the cultivation of maize, providing grain yields that can surpass 20 tons per hectare. However, yields are not always optimal, due to parameters related to climatic and soil conditions. The air temperature and rainfall data were collected from meteorological stations located at the experimental sites. Nea Tyroloi and Kamila shared one meteorological station, as they are on the plain of Serres, with a distance lower than $5 \mathrm{~km}$. The mean monthly maximum temperature was the mean value of the recorded monthly maximum temperatures during the study period, whereas the mean monthly minimum temperature was the mean value of the recorded monthly minimum temperatures (Table 2). For the irrigation of maize cultivation, surface irrigation was used. A laser guided land leveler was used, which is nowadays a common agricultural practice in Greece, at all the experimental fields in order to assure equal water availability at all sites. Each irrigation dose had a duration up to $24 \mathrm{~h}$. The irrigation was conducted according to the soil needs for optimum water conditions.

Table 2. Climatic conditions for the 12 examined environments during the cultivation period (March-September).

\begin{tabular}{cccccc}
\hline Environment & Location and Year & $\begin{array}{c}\text { Mean Monthly } \\
\text { Maximum } \\
\text { Temperature }\left({ }^{\circ} \mathbf{C}\right)\end{array}$ & $\begin{array}{c}\text { Mean Monthly } \\
\text { Minimum } \\
\text { Temperature }\left({ }^{\circ} \mathbf{C}\right)\end{array}$ & $\begin{array}{c}\text { Mean } \\
\text { Temperature }\left({ }^{\circ} \mathbf{C}\right)\end{array}$ & Total Rain (mm) \\
\hline ENV1 & Giannouli 2017 & 37.7 & 11.4 & 22.2 & 365.8 \\
ENV2 & Giannouli 2018 & 34.6 & 12.8 & 22.4 & 21.3 \\
ENV3 & Giannitsa 2017 & 34.8 & 9.9 & 21.4 & 206.6 \\
ENV4 & Giannitsa 2018 & 32.5 & 10.0 & 20.8 & 340.6 \\
ENV5 & Nea Tyroloi * 2017 & 34.7 & 9.2 & 20.8 & 261.0 \\
ENV6 & Nea Tyroloi 2018 & 32.0 & 8.7 & 20.8 & 434.8 \\
ENV7 & Kamila * 2017 & 34.7 & 8.2 & 20.8 & 261.0 \\
ENV8 & Kamila 2018 & 32.0 & 8.7 & 19.7 & 434.8 \\
ENV9 & Kalamonas 2017 & 32.7 & 9.1 & 20.4 & 265.0 \\
ENV10 & Kalamonas 2018 & 31.4 & 10.3 & 20.8 & 273.4 \\
ENV11 & Koutso 2017 & 33.2 & 10.7 & 21.3 & 259.8 \\
ENV12 & Koutso 2018 & 31.6 & & 487.2 \\
\hline
\end{tabular}

* Nea Tyroloi and Kamila share the same climatic conditions. 
The selected locations presented variability regarding the soil texture and $\mathrm{pH}$ values (Table 3). Organic matter was very low (1.3-2.0\%) in all environments, total nitrogen was low $(0.56-1.66 \mathrm{mg} / \mathrm{g})$, available $\mathrm{P}$ was medium to high $(12-44 \mathrm{~mm} / \mathrm{kg})$, exchangeable $\mathrm{K}$ was medium-low to medium-high $(0.29-0.54 \mathrm{cmo} \ell+/ \mathrm{kg})$, and the cation exchange capacity (CEC) ranged from 11 to $25 \mathrm{cmo} \ell+/ \mathrm{kg}$. A 30-5-5 granular fertilizer (500 kg per ha) was added with base application (at sowing), and a 46-0-0 granular fertilizer (300 kg per ha) was applied in season (approximately 7-8 weeks after sowing) with side dressing.

Table 3. Physicochemical properties of soil for the 12 environments. C, clay; SL, sandy loam; CL, clay loam; L, loam; CEC, cation exchange capacity.

\begin{tabular}{|c|c|c|c|c|c|c|c|}
\hline Environment & Soil Texture & $\mathrm{pH}$ & Organic Matter (\%) & $\begin{array}{c}\text { Total Nitrogen } \\
(\mathrm{mg} / \mathrm{g})\end{array}$ & $\begin{array}{c}\text { Available P } \\
\text { (mg/kg) }\end{array}$ & $\begin{array}{c}\text { Exchangeable K } \\
(\mathrm{cmo} \ell+/ \mathrm{kg})\end{array}$ & $\mathrm{CEC}(\mathrm{cmo} \ell+/ \mathrm{kg})$ \\
\hline ENV1 & C & 7.7 & 1.5 & 0.56 & 22 & 0.58 & 23 \\
\hline ENV2 & C & 7.8 & 1.5 & 0.63 & 33 & 0.45 & 25 \\
\hline ENV3 & C & 7.2 & 1.3 & 0.71 & 39 & 0.36 & 14 \\
\hline ENV4 & C & 7.2 & 1.4 & 0.84 & 44 & 0.47 & 17 \\
\hline ENV5 & SL & 7.6 & 1.3 & 0.77 & 40 & 0.38 & 18 \\
\hline ENV6 & SL & 7.7 & 2.0 & 0.98 & 42 & 0.45 & 22 \\
\hline ENV7 & $\mathrm{CL}$ & 7.7 & 1.8 & 1.12 & 16 & 0.38 & 21 \\
\hline ENV8 & CL & 7.7 & 1.8 & 1.66 & 22 & 0.64 & 24 \\
\hline ENV9 & SL & 6.1 & 1.6 & 0.72 & 12 & 0.29 & 15 \\
\hline ENV10 & SL & 6.5 & 1.7 & 1.04 & 19 & 0.37 & 15 \\
\hline ENV11 & $\mathrm{L}$ & 5.8 & 1.2 & 0.82 & 27 & 0.46 & 11 \\
\hline ENV12 & $\mathrm{L}$ & 6.1 & 1.6 & 0.58 & 44 & 0.50 & 16 \\
\hline
\end{tabular}

\subsubsection{Maize Hybrids}

The five maize hybrids that were selected have been widely cultivated all over Greece during the last few years, and they are considered to be among the most high-yielding hybrids with good adaption to many environmental conditions. GEN1 was P0937 (Pioneer Hi-Bred Hellas S.A.), a 500 FAO group hybrid with 120-125 days to maturity, with high yield. GEN2 was DKC6050 (K. \& N. Efthymiadis S.A.), a 600 FAO group hybrid with 116-123 days to maturity. It has a solid ear, with fill up to the top ears with 16-18 rows of kernels. This hybrid is considered to have high yield stability and good adaptation to many environments. GEN 3 was DKC6442 (K. \& N. Efthymiadis S.A.), a 600 FAO group hybrid with 116-123 days to maturity. It has long and solid ear, with fill up to the top ears with 16-18 rows of kernels. This hybrid is considered to have a very high yield in high-yielding environments. GEN4 was DKC6980 (K. \& N. Efthymiadis S.A.), a 700 FAO group hybrid with 130-136 days to maturity. It has a large ear, with 18-20 rows of kernels. This hybrid is considered to have a very high yield dynamic and yield stability even in environments with high temperatures. GEN5 was PR31Y43 (Pioneer Hi-Bred Hellas S.A.), a 700 FAO group hybrid with 135-140 days to maturity.

\subsection{Soil Sample Analyses}

Soil samples were collected from each location for every year of the experiment. Soil texture was determined using the method of Bouyoucos [19] with the classification of the Soil Taxonomy of the United States Department of Agriculture (USDA) (1999). The $\mathrm{pH}$ was measured using a $\mathrm{pH}$-meter equipped with a glass electrode in saturated paste extract. Organic matter was determined via oxidization by $\mathrm{K}_{2} \mathrm{Cr}_{2} \mathrm{O}_{7}$ [20], total nitrogen was determined using the Kjeldahl method [21], available phosphorus was determined after extraction with $\mathrm{NaHCO}_{3}$ [22], exchangeable $\mathrm{K}$ was determined via atomic absorption spectrometry after extraction using $\mathrm{BaCl}_{2}$ [23], and cation exchange capacity was determined according to the International Organization for Standardization (ISO) 11260 [23].

\subsection{Statistical Analysis}

Additive main effects and multiplicative interaction (AMMI) analysis was conducted using AMMISOFT version 1.0 (Soil and Crop Sciences, Cornell University, Ithaca, NY, USA). 


\section{Results and Discussion}

The results of ANOVA (Table 4 ) indicate that, regarding grain yield $(\mathrm{kg} / \mathrm{ha})$, genotypes $(\mathrm{GEN})$, environments $(\mathrm{ENV})$, and their interaction $(\mathrm{G} \times \mathrm{E})$ were statistically significant $(p<0.001)$. According to the results, the $\mathrm{G} \times \mathrm{E}$ effect explained $80.36 \%$ of the variation, while GEN explained only $12.79 \%$, with the remainder explained by ENV (6.85\%). For this reason, AMMI analysis was deemed valuable to explain this high effect of $G \times E$, in order to identify and divide the region into mega-environments, where the $\mathrm{G} \times \mathrm{E}$ interactions are positive. Interaction principal component 1 (IPC1), IPC2, and IPC 3 were statistically significant $(p<0.001)$ and the AMMI model explained $96.21 \%$ of the total $G \times$ $E$ interaction. The result of AMMI analysis provides information on which genotype to use in which environment in order to achieve an increase in yield. Depending on the genetic material used, as well as the heterogeneity of the selected environments, similar maize grain yield experiments can present huge variation as a function of $G, E$, and $G \times E$ effects. Usually, the main environment effects account for more than $75 \%$ of the variation $[3,24-26]$. However, large $\mathrm{G} \times \mathrm{E}$ interaction effects are common in agricultural studies as it was found at the evaluation of yield of lentil [27] and rice [28] genotypes. When GE interaction effects are high, then the target to increase yield can be accomplished by dividing the experimental region into mega-environments and exploiting positive GE interactions of genotypes and environments. Moreover, this analysis contributes to the selection and successful introduction of new cultivars in the most suitable environments [6].

Table 4. Additive main effects and multiplicative interaction (AMMI) analysis of variance for grain yield ( $\mathrm{kg} / \mathrm{ha})$.

\begin{tabular}{cccccc}
\hline Source & df & SS & MS & SS\% & SS\% of G $\times$ E \\
\hline Total & 179 & $904,140,852$ & $5,051,066$ & & \\
TRT & 59 & $866,368,551$ & $14,684,212^{* * *}$ & & \\
GEN & 4 & $110,806,319$ & $27,701,579 * * *$ & 12.79 & 70.25 \\
ENV & 11 & $59,324,671$ & $5,393,151^{* * *}$ & 6.85 & 18.21 \\
G $\times$ E & 44 & $696,237,559$ & $15,823,580^{* * *}$ & 80.36 & 7.75 \\
IPC1 & 14 & $489,123,459$ & $34,937,389 * * *$ & & \\
IPC2 & 12 & $126,812,161$ & $10,567,680^{* * *}$ & & \\
IPC3 & 10 & $53,924,466$ & $5,392,446 * * *$ & & \\
Residual & 8 & $26,377,472$ & $3,297,184 * * *$ & & \\
Error & 120 & $37,772,301$ & 314,769 & & \\
Blocks/ENV & 24 & $8,602,227$ & 358,426 & & \\
Pure Error & 96 & $29,170,074$ & 303,854 & & \\
\hline *** Significant at 0.001. & & & &
\end{tabular}

According to the biplot of mean grain yield $(\mathrm{kg} / \mathrm{ha})$ and the first interaction principal component (Figure 1), GEN5 had the highest mean yield (17,670 kg/ha), followed by GEN4 $(17,602 \mathrm{~kg} / \mathrm{ha})$, GEN2 (16,700 kg/ha), GEN1 (15,893 kg/ha), and GEN3 (15,874 kg/ha). GEN5 was also the most stable genotype with an IPC1 score close to zero compared to the other genotypes. The IPC1 values of GEN3 and GEN4 were not very far from the zero axis, while GEN1 and GEN2 had high values of IPC1 and were considered as not stable. Concerning environments, ENV6, ENV3, and ENV12 had IPC1 values close to zero and close to the mean yield $(17,102,16,713$, and $16,591 \mathrm{~kg} / \mathrm{ha}$, respectively). ENV8 had the highest mean yield (17,723 kg/ha), while ENV1 had the lowest $(15,292 \mathrm{~kg} / \mathrm{ha})$. 


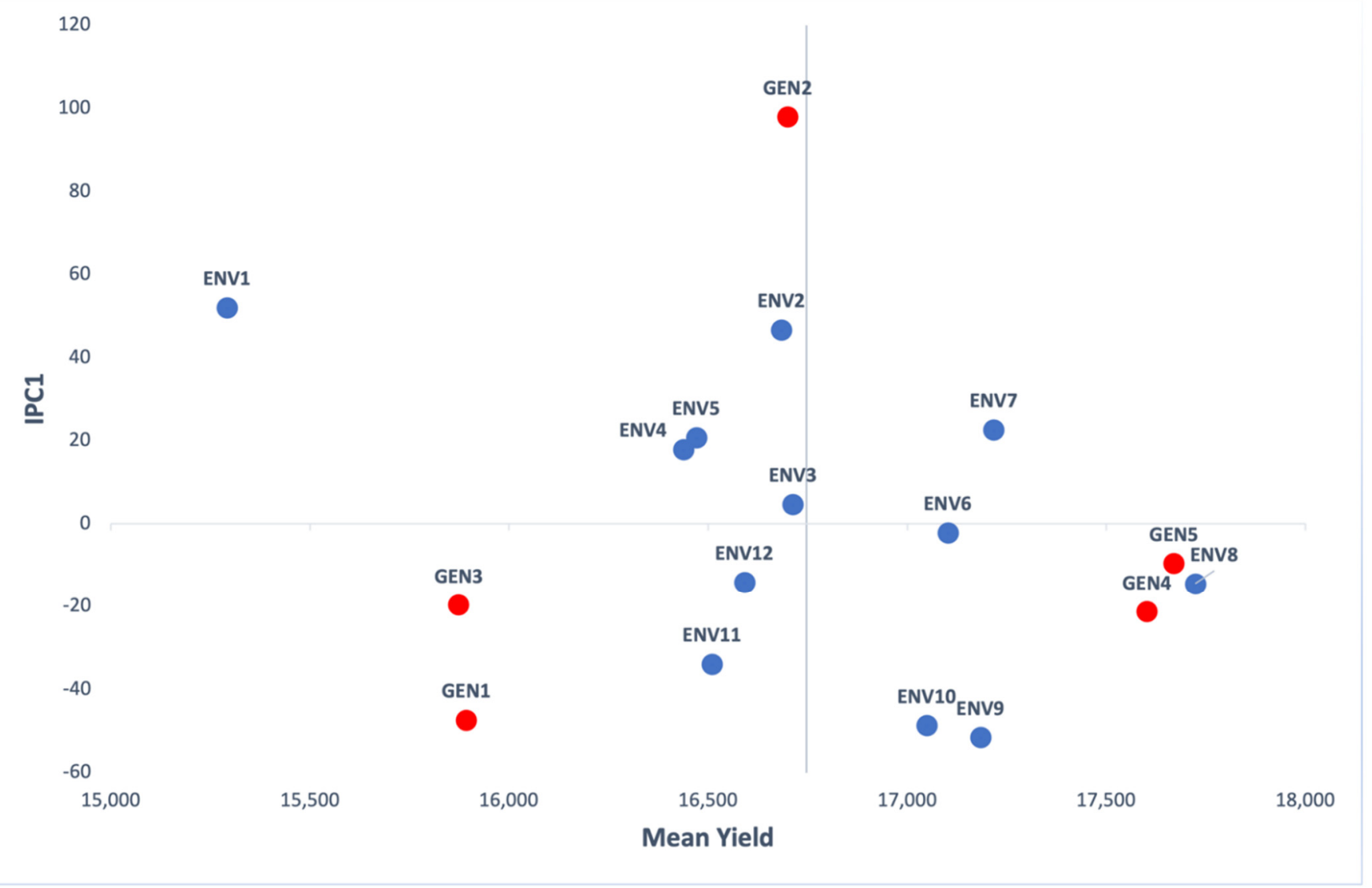

Figure 1. AMMI biplot presenting mean grain yield (kg/ha) and the first interaction principal component (IPC1) of five genotypes evaluated in 12 environments.

AMMI analysis in multi-environment field trials is commonly used as a tool to evaluate maize hybrids $[9,15,16,29]$. The most common objective of the studies using AMMI analysis is to evaluate several genotypes in environments with similar or completely different characteristics, so as to determine the quantity and the quality of the yield. For instance, Hongyu et al. [29] in a similar experiment evaluated the productivity of nine maize genotypes in a multi-environment experiment (20 environments) with respect to adaptability, in addition to observing the effect of the genotype $\times$ environment interaction. Similar to our study, hybrids with different FAO maturity (300-700) have been used for the evaluation of maize grain yield in Serbia, in a multi-environment experiment, using AMMI analysis (300-700) [26]. The increasing number of studies using AMMI analysis to evaluate different genotypes in different environments, defined by soil and climatic conditions, has contributed to a better understanding of the complex genotype $\times$ environment interactions and enhanced breeding efficiency $[9,30,31]$, as well as the selection of the most suitable hybrids for the maize producers all over the world.

AMMI analysis has also been used to evaluate yield for cultivars of many other species such as wheat [13,32], sugarcane [14], oilseed rape [11], and barley [10], as well as quality characteristics such as 1000-kernel weight in spring barley [33] and nutritional composition of sweet potato [34].

It is noted that the first two principal components in AMMI analysis were significant, explaining $88.46 \%$ of the variation in G $\times$ E interaction (70.25\% IPC1 and $18.21 \%$ IPC2) (Table 4). According to the biplot of the first (IPC1) and the second (IPC2) interaction principal components (Figure 2), GEN4 had a positive interaction with ENV6, ENV8, and ENV12. When a genotype and an environment are close and have the same direction from the origin, this means that they have a positive interaction [35]. It is important to note 
that the highest rain precipitation during the cultivation period was recorded in these environments. GEN2 had a positive interaction with ENV1, ENV2, ENV3, ENV5, and ENV7, where the mean monthly high temperature was over $34^{\circ} \mathrm{C}$, according to the climatic data during the cultivation period (Table 2). Specifically, GEN2 which was located furthest from the biplot origin, contributed the largest $\mathrm{G} \times \mathrm{E}$ interaction for yield. Moreover, the four environments with slightly acidic pH (ENV9, ENV10, ENV11, and ENV12) had a positive interaction with all genotypes studied, except GEN2. Maize usually presents better results in neutral or slightly acidic soils; however, it can often be found in even more acidic soils. In these soils, maize can still produce increased yield, especially when cultivated with acid-tolerant cultivars [36]. Maize plants are sensitive to high temperatures, and yield is typically decreased over $32{ }^{\circ} \mathrm{C}$ as the optimal growth ranges between $28^{\circ} \mathrm{C}$ and $32{ }^{\circ} \mathrm{C}$ [37].

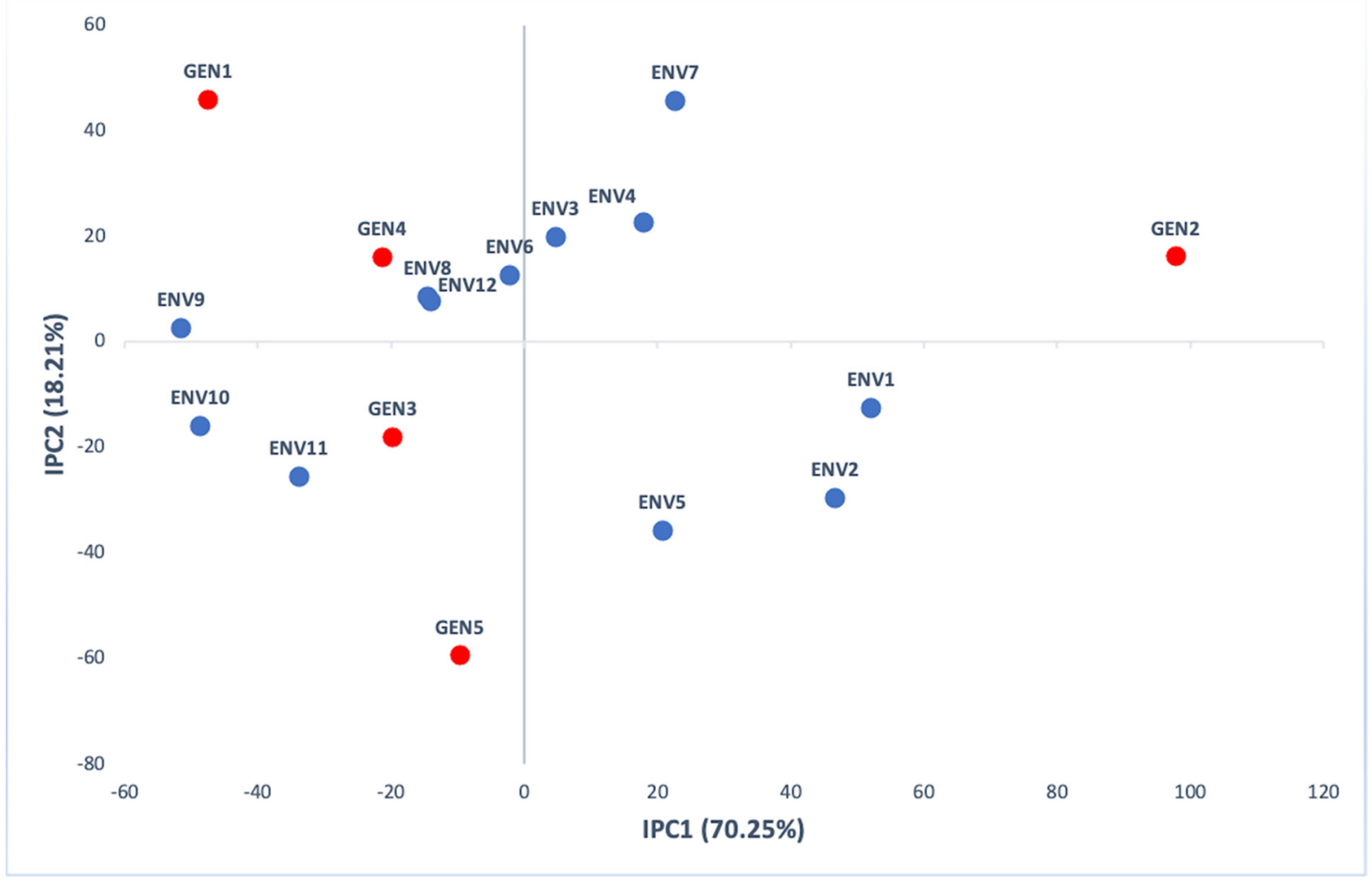

Figure 2. AMMI biplot presenting the second interaction principal components (IPC2) versus the first interaction principal components (IPC1) scores for grain yield ( $\mathrm{kg} / \mathrm{ha})$ of five genotypes evaluated in 12 environments.

Giannouli was the location with the highest mean temperature during the cultivation period (March-September) for both years (22.2 and 22.4 ${ }^{\circ} \mathrm{C}$ in 2017 (ENV1) and 2018 (ENV2), respectively). The lowest mean temperature was recorded at Kalamonas for both years (19.7 and $20.4{ }^{\circ} \mathrm{C}$ in 2017 (ENV9) and 2018 (ENV10), respectively). At Koutso (ENV12), as well as Nea Tyroloi (ENV6) and Kamila (ENV8), which are neighboring locations, a relatively high total precipitation ( 487.2 and $434.8 \mathrm{~mm}$, respectively) was recorded in 2018 for the climatic conditions of Greece during the summer. The lowest precipitation during the cultivation period was recorded at Giannitsa (ENV3) in 2017 (206.6 mm).

The evaluation of environmental groups with varying climate conditions usually leads to a high $\mathrm{G} \times \mathrm{E}$ interaction, which means that each group has different top-yielding genotypes [38]. Thus, when the $\mathrm{G} \times \mathrm{E}$ interaction component is large, no single genotype shows consistency with respect to a high grain yield [39]. In many studies, the megaenvironments derived from AMMI analysis were characterized by climatic conditions. For example, in a recent study of maize evaluation, the temperature of the environment determined the creation of the mega-environments, as well as the year [40]. Parameters 
such as the quantity of rain, the soil type, and the nitrogen availability are considered of major importance in such studies, and environments sharing the same location are typically ideal for certain genotypes [30]. In maize hybrid evaluation experiments, similar to our results, the genotypes presented specific adaptability to favorable environments $[9,15,41]$. In a similar research in Spain, climatic conditions affected the yield of maize. Specifically, the days with mean temperature over $15^{\circ} \mathrm{C}$ during the first weeks after sowing were found to have negative effect on maize grain yield, while the maximum temperature of September (up to $28.9^{\circ} \mathrm{C}$ ) when the plants are on the stage of seed filling was found to have a positive effect on yield [42]. In Serbia, in a maize grain yield evaluation, high mean temperature of July affected less the yield of medium early maturing hybrids than late maturing hybrids, while the amount of precipitation (rainfed cultivation) in June was significantly correlated with grain yield [26].

The AMMI analysis provided a table (Table 5) with the winning genotypes for each AMMI model family in order to identify the mega-environments [7]. Concerning AMMI model families, those to the left of the suitable AMMI model were too simple and, thus, underfitted the real signal, whereas models to the right were too complex and, thus, overfitted spurious noise (AMMI F denotes the full model or actual data). According to the first AMMI model, GEN2, GEN4, and GEN5 resulted in the most narrow adaptations, and these were the most suitable genotypes for the three mega-environments delineated (Table 5). The first mega-environment consisted of five environments (ENV1, ENV2, ENV4, ENV5, and ENV7) in which GEN2 was the best-adapted genotype. The second mega-environment consisted of two environments (ENV3 and ENV6) with GEN5 being the best-suited genotype. The third mega-environment included five environments (ENV8, ENV9, ENV10, ENV11, and ENV12) in which GEN4 presented the best results. The genotypes and environments tested are listed in Table 6 according to their IPC1 order. The best and worst performances in terms of IPC1 showed the opposite $G \times$ E pattern [11]. As an example, GEN2 had a positive $\mathrm{G} \times \mathrm{E}$ with ENV1 and ENV2 and a negative $\mathrm{G} \times \mathrm{E}$ with ENV9, in which GEN1 had a positive interaction. When AMMI analysis results show narrow adaptations, it is quite common that even genotypes with high IPC scores and yield values might not be widely stable; however, they are the best-suited option in a certain environment [15].

Table 5. AMMI family models for the grain yield dataset, showing the best-suited genotypes and the number of mega-environments.

\begin{tabular}{ccccccc}
\hline \multicolumn{2}{l}{ Yield } & \multicolumn{5}{c}{ AMMI Model Family } \\
\hline \multicolumn{2}{c}{ Genotype } & $\mathbf{0}$ & $\mathbf{1}$ & $\mathbf{2}$ & $\mathbf{3}$ & F \\
\hline 2 & GEN2 & & 5 & 4 & 4 & 4 \\
5 & GEN5 & 12 & 2 & 3 & 3 & 4 \\
4 & GEN4 & & 5 & 5 & 5 & 4 \\
\hline \multicolumn{2}{l}{ Mega-environments } & 1 & 3 & 3 & 3 & 3 \\
\hline
\end{tabular}


Table 6. Ranking of the genotypes and the environments according to their IPC1 scores for grain yield.

\begin{tabular}{cccc}
\hline Genotype & Code & IPC1 Score & Mean Yield (kg/ha) \\
\hline 2 & GEN2 & 97.93 & 16,700 \\
5 & GEN5 & -9.63 & 17,671 \\
3 & GEN3 & -19.642 & 15,874 \\
4 & GEN4 & -21.26 & 17,603 \\
1 & GEN1 & -47.41 & 15,894 \\
\hline Environment & & & \\
\hline 1 & ENV1 & 52.09 & 15,293 \\
2 & ENV2 & 46.72 & 16,684 \\
7 & ENV7 & 22.69 & 17,218 \\
5 & ENV5 & 20.77 & 16,471 \\
4 & ENV4 & 17.85 & 16,439 \\
3 & ENV3 & 4.70 & 16,713 \\
6 & ENV6 & -2.17 & 17,102 \\
12 & ENV12 & -14.10 & 16,592 \\
8 & ENV8 & -14.46 & 17,723 \\
11 & ENV11 & -33.89 & 16,510 \\
10 & ENV10 & -48.67 & 17,050 \\
9 & ENV9 & -51.54 & 17,184 \\
\hline
\end{tabular}

\section{Conclusions}

As an increase in yield remains a constant demand of growers worldwide, researchers have focused on providing efficient results for which genotype to use in which environment, in order to contribute to the effort to increase crop productivity. According to the first AMMI model, GEN2, GEN4, and GEN5 were the most suitable genotypes for the three mega-environments delineated. Moreover, the AMMI biplot presenting IPC2 vs. IPC1 scores for the grain yield $(\mathrm{kg} / \mathrm{ha})$ of five genotypes evaluated in 12 environments indicated that ENV9, ENV10, ENV11, and ENV12, where the soil was slightly acidic, had a positive interaction with all hybrids except GEN2. Even though slightly acidic soils are considered optimal for maize cultivation, our results show that GEN2 is not suited for soils with this characteristic. Additionally, GEN4 showed a positive interaction with ENV6, ENV8, and ENV12. These findings can be attributed to the fact that these locations recorded the highest rain precipitation $(>400 \mathrm{~mm}$ ) among the studied environments. It is important to note that the hottest environments, with the highest values in all three temperature measurements (mean monthly high, mean monthly low, and mean temperature), led to low or average yield. This study provides a valuable dataset (five representative commercial maize hybrids $\times$ six locations where maize is traditionally cultivated in Greece $\times$ two years) with results that can be exploited by breeders, seed industry companies, and farmers. AMMI analysis suggests that an increase in yield can be accomplished by dividing experimental regions into three mega-environments to exploit positive $\mathrm{G} \times \mathrm{E}$ interactions. The positive interaction of certain hybrids in environments with certain physicochemical soil properties and climatic conditions can be valuable for the scientific community. However, further multi-environment trials (determined by soil and climatic conditions) using more genotypes and investigating grain quality characteristics should be performed.

Author Contributions: Conceptualization, N.K. and A.E.; methodology, N.K., P.S., D.L., I.K., D.V. and A.E.; software, N.K. and P.S.; validation, D.L., D.V., G.K. and A.E.; formal analysis, N.K., P.S., G.K. and D.L.; investigation, N.K., P.S., D.L., I.K., D.V. and A.E.; resources, N.K., P.S., D.L. and A.E.; writing—original draft preparation, N.K. and P.S.; writing—review and editing, N.K., P.S., D.L., I.K., D.V. and A.E.; supervision, A.E.; project administration, N.K., D.L. and D.V. All authors have read and agreed to the published version of the manuscript.

Funding: This research received no external funding.

Informed Consent Statement: Not applicable. 
Data Availability Statement: The data presented in this study are available on request from the corresponding author.

Conflicts of Interest: The authors declare no conflict of interest.

\section{References}

1. FAO_Food and Agriculture Organization of the United Nations. FAOSTAT Statistical Database; FAO: Rome, Italy, 2018.

2. Duvick, D.N. The Contribution of Breeding to Yield Advances in maize (Zea mays L.). Adv. Agron. 2005, 86, 83-145. [CrossRef]

3. Epinat-Le Signor, C.; Dousse, S.; Lorgeou, J.; Denis, J.; Bonhomme, R.; Carolo, P.; Charcosset, A. Interpretation of genotype $\mathrm{x}$ environment interactions for early maize hybrids over 12 years. Crop Sci. 2001, 41, 663-669. [CrossRef]

4. Lu'quez, J.E.; Aguirrezábal, L.A.N.; Agüero, M.E.; Pereyra, V.R. Stability and adaptability of cultivars in non-balanced yield trials: Comparison of methods for selecting 'high oleic' sunflower hybrids for grain yield and quality. J. Agron. Crop Sci. 2002, 188, 225-234. [CrossRef]

5. Yan, W.; Kang, M.S.; Ma, B.; Woods, S.; Cornelius, P.L. GGE Biplot vs. AMMI Analysis of Genotype-by-Environment Data. Crop Sci. 2007, 47, 643-653. [CrossRef]

6. Shahriari, Z.; Heidari, B.; Dadkhodaie, A. Dissection of genotype $\times$ environment interactions for mucilage and seed yield in Plantago species: Application of AMMI and GGE biplot analyses. PLoS ONE 2018, 13, e0196095. [CrossRef]

7. Gauch, H.G., Jr. A Simple Protocol for AMMI Analysis of Yield Trials. Crop Sci. 2013, 53, 1860-1869. [CrossRef]

8. Singh, C.; Gupta, A.; Gupta, V.; Kumar, P.; Sendhil, R.; Tyagi, B.; Singh, G.; Chatrath, R.; Singh, G. Genotype x environment interaction analysis of multi-environment wheat trials in India using AMMI and GGE biplot models. Crop Breed. Appl. Biotechnol. 2019, 19, 309-318. [CrossRef]

9. Abate, M. Genotype by environment interaction and yield stability analysis of open pollinated maize varieties using AMMI model in Afar Regional State, Ethiopia. J. Plant Breed. Crop Sci. 2020, 12, 8-15. [CrossRef]

10. Kiliç, H. Additive Main Effects and Multiplicative Interactions (AMMI) Analysis of Grain Yield in Barley Genotypes across Environments. J. Agric. Sci. 2014, 20, 337-344. [CrossRef]

11. Agahi, K.; Ahmadi, J.; Oghan, H.A.; Fotokian, M.H.; Orang, S.F. Analysis of genotype $\times$ environment interaction for seed yield in spring oilseed rape using the AMMI model. Crop Breed. Appl. Biotechnol. 2020, 20, e26502012. [CrossRef]

12. Morgounov, A.; Gómez-Becerra, H.F.; Abugalieva, A.; Dzhunusova, M.; Yessimbekova, M.; Muminjanov, H.; Zelenskiy, Y.; Ozturk, L.; Cakmak, I. Iron and zinc grain density in common wheat grown in Central Asia. Euphytica 2007, 155, 193-203. [CrossRef]

13. Li, W.; Yan, Z.H.; Wei, Y.M.; Lan, X.J.; Zheng, Y.L. Evaluation of Genotype $\times$ Environment Interactions in Chinese Spring Wheat by the AMMI Model, Correlation and Path Analysis. J. Agron. Crop Sci. 2006, 192, 221-227. [CrossRef]

14. Da Silveira, L.C.; Kist, V.; de Paula, T.O.M.; Barbosa, M.H.P.; Peternelli, L.A.; Daros, E. AMMI analysis to evaluate the adaptability and phenotypic stability of sugarcane genotypes. Sci. Agric. 2013, 70, 27-32. [CrossRef]

15. Mafouasson, H.N.A.; Gracen, V.; Yeboah, M.A.; Ntsomboh-Ntsefong, G.; Tandzi, L.N.; Mutengwa, C.S. Genotype-by-Environment Interaction and Yield Stability of Maize Single Cross Hybrids Developed from Tropical Inbred Lines. Agronomy $2018,8,62$. [CrossRef]

16. Mitrović, B.; Stanisavljevi, D.; Treski, S.; Stojaković, M.; Ivanović, M.; Bekavac, G.; Rajković, M. Evaluation of experimental maize hybrids tested in multi-location trials using ammi and gge biplot analyses. Turk. J. Field Crop. 2012, 17, 35-40.

17. Sadeghzadeh, B.; Mohammadi, R.; Ahmadi, H.; Abediasl, G.R.; Ahmadi, M.M.; Mohammadfam, M.; Bahrami, N.; Khaledian M.S.; Naserian, A.A. GGE biplot and AMMI application in the study of adaptability and grain yield stability of durum lines under dryland conditions. Environ. Stresses Crop Sci. 2018, 11, 241-260. [CrossRef]

18. Matus-Cádiz, M.A.; Hucl, P.; Perron, C.E.; Tyler, R.T. Genotype x environment interaction for grain color in hard white spring wheat. Crop Sci. 2003, 43, 219-226. [CrossRef]

19. Bouyoucos, G.J. Hydrometer method improved for making particle and size analysis of soils. Agron. J. 1962, 54, 464-465. [CrossRef]

20. International Standard Organisation (ISO). ISO 14235:1998. Soil Quality_Determination of Organic Carbon by Sulfochromic Oxidation; ISO: Geneva, Switzerland, 1998.

21. International Standard Organisation (ISO). ISO 11261:1995. Soil Quality—Determination of Total Nitrogen-Modified Kjeldahl Method; ISO: Geneva, Switzerland, 1995.

22. International Standard Organisation (ISO). ISO 11263:1994. Soil Quality—Determination of Phosphorus—Spectrometric Determination of Phosphorus Soluble in Sodium Hydrogen Carbonate Solution; ISO: Geneva, Switzerland, 1994.

23. International Standard Organisation (ISO). ISO 11260:1994. Soil Quality—Determination of Effective Cation Exchange Capacity and Base Saturation Level Using Barium Chloride Solution; ISO: Geneva, Switzerland, 1994.

24. Alwala, S.; Kwolek, T.; McPherson, M.; Pellow, J.; Meyer, D. A comprehensive comparison between Eberhart and Russell joint regression and GGE biplot analyses to identify stable and high yielding maize hybrids. Field Crop. Res. 2010, 119, 225-230. [CrossRef]

25. Badu-Apraku, B.; Oyekunle, M.; Obeng-Antwi, K.; Osuman, A.; Ado, S.; Coulibay, N.; Yallou, C.; Abdulai, M.; Boakyewaa, G.; Didjeira, A. Performance of extra-early maize cultivars based on GGE biplot and AMMI analysis. J. Agric. Sci. 2012, 150, 473-483. [CrossRef] 
26. Branković-Radojĉić, D.; Babić, V.; Girek, Z.; Tुivanović, T.; Radojĉić, A.; Filipović, M.; Srdić, J. Evaluation of maize grain yield and yield stability by AMMI analysis. Genetika 2018, 50, 1067-1080. [CrossRef]

27. Sabaghnia, N.; Dehghani, H.; Sabaghpour, S.H. Nonparametric Methods for Interpreting Genotype 3 Environment Interaction of Lentil Genotypes. Crop Sci. 2006, 46, 1100-1106. [CrossRef]

28. Sharifi, P.; Aminpanah, H.; Erfani, R.; Mohaddesi, A.; Abbasian, A. Evaluation of Genotype $\times$ Environment Interaction in Rice Based on AMMI Model in Iran. Rice Sci. 2017, 24, 173-180. [CrossRef]

29. Hongyu, K.; García-Peña, M.; Araújo, L.; Santos Dias, C. Statistical analysis of yield trials by AMMI analysis of genotype $\times$ environment interaction. Biom. Lett. 2014, 51, 89-102. [CrossRef]

30. Ndhlela, T.; Herselman, L.; Magorokosho, C.; Setimela, P.; Mutimaamba, C.; Labuschagne, M. Genotype $\times$ Environment Interaction of Maize Grain Yield Using AMMI Biplots. Crop Sci. 2014, 54, 1992-1999. [CrossRef]

31. Crossa, J.; Fox, P.N.; Pfeiffer, W.H.; Rajaram, S.; Gauch, H.G., Jr. AMMI adjustment for statistical analysis of an international wheat yield trial. Theor. Appl. Genet. 1991, 81, 27-37. [CrossRef]

32. Farshadfar, E.; Mahmodi, N.; Yaghotipoor, A. AMMI stability value and simultaneous estimation of yield and yield stability in bread wheat (Triticum aestivum L.). Aust. J. Crop Sci. 2011, 5, 1837-1844.

33. Bocianowski, J.; Warzecha, T.; Nowosad, K.; Bathelt, R. Genotype by environment interaction using AMMI model and estimation of additive and epistasis gene effects for 1000-kernel weight in spring barley (Hordeum vulgare L.). J. Appl. Genet. 2019, 60, 127-135. [CrossRef]

34. Gurmu, F.; Shimelis, H.; Laing, M.; Mashilo, J. Genotype-by-environment interaction analysis of nutritional composition in newly-developed sweetpotato clones. J. Food Compos. Anal. 2020, 88, 10342. [CrossRef]

35. Gauch, H.G., Jr.; Moran, D.R. AMMISOFT for AMMI Analysis with Best Practices. bioRxiv 2019, 538454. [CrossRef]

36. The, C.; Calba, H.; Zonkeng, C.; Ngonkeu, E.L.M.; Adetimirin, V.O.; Mafouasson, H.A.; Meka, S.S.; Horst, W.J. Responses of maize grain yield to changes in acid soil characteristics after soil amendments. Plant Soil 2006, 284, 45-57. [CrossRef]

37. Sánchez, B.; Rasmussen, A.; Porter, J.R. Temperatures and the growth and development of maize and rice: A review. Glob. Chang. Biol. 2014, 20, 408-417. [CrossRef]

38. Mohammadi, R.; Sadeghzadeh, D.; Armion, M.; Amri, A. Evaluation of durum wheat experimental lines under different climate and water regime conditions of Iran. Crop Pasture Sci. 2011, 62, 137-151. [CrossRef]

39. Bertero, H.D.; de la Vega, A.J.; Correa, G.; Jacobsen, S.E.; Mujica, A. Genotype and genotype-by-environment interaction effects for grain yield and grain size of quinoa (Chenopodium quinoa Willd.) as revealed by pattern analysis of international multi-environment trials. Field Crop. Res. 2004, 89, 299-318. [CrossRef]

40. Abakemal, D.; Shimelis, H.; Derera, J. Genotype-by-environment interaction and yield stability of quality protein maize hybrids developed from tropical-highland adapted inbred lines. Euphytica 2016, 209, 757-769. [CrossRef]

41. Faria, S.V.; Luz, L.S.; Rodrigues, M.C.; Carneiro, J.E.S.; Carneiro, P.C.S.; DeLima, R.O. Adaptability and stability in commercial maize hybrids in the southeast of the State of Minas Gerais, Brazil. Rev. Ciência Agronômica 2017, 48, 347-357. [CrossRef]

42. Romay, M.C.; Malvar, R.A.; Campo, L.; Alvarez, A.; Moreno-González, J.; Ordás, A.; Revilla, P. Climatic and Genotypic Effects for Grain Yield in Maize under Stress Conditions. Crop Sci. 2010, 50, 51-58. [CrossRef] 